Paper no. 2010/13

\title{
Are knowledge-bases enough? A comparative study of the geography of knowledge sources in China (Great
Beijing) and India (Pune) knowledge sources in China (Great
Beijing) and India (Pune)
}

Cristina Chaminade (cristina.chaminade@circle.lu.se)

Circle, Lund University, Sweden

This is a pre-print version of a paper that has been submitted for publication to European Planning Studies

This version: December 2010

Centre for Innovation, Research and Competence in the Learning Economy (CIRCLE) Lund University

P.O. Box 117, Sölvegatan 16, S-221 00 Lund, SWEDEN

http://www.circle.lu.se/publications

ISSN 1654-3149 
WP 2010/13

Are knowledge-bases enough? A comparative study of the geography of knowledge sources in China (Great Beijing) and India (Pune)

Cristina Chaminade

\begin{abstract}
This paper focuses on the organization and geography of interactions between firms and other organizations in two industries: software and autoparts. In contrast to most recent literature in economic geography that argues that industries differ in their knowledge bases and that consequently different industries show different patterns of local-global interactions, our results show stronger differences between regions in the same industry than between industries in the same region, thus pointing out to other factors explaining the geography of innovation in that particular industry.
\end{abstract}

Keywords: internationalization, innovation, Pune, Beijing, region

Disclaimer: All the opinions expressed in this paper are the responsibility of the individual author or authors and do not necessarily represent the views of other CIRCLE researchers. 


\section{RESEARCH BRIEFING}

Forthcoming in 2011 in European Planning Studies

\section{ARE KNOWLEDGE-BASES ENOUGH? A COMPARATIVE STUDY OF THE GEOGRAPHY OF KNOWLEDGE SOURCES IN CHINA (GREAT BEIJING) AND INDIA (PUNE)}

Cristina Chaminade, CIRCLE, Lund University, Sweden

PO Box 117 Lund

Sweden.

cristina.chaminade@circle.lu.se

Acknowledgements: This project has been financed by the Swedish Research Council (421-2006-2332). My special thanks to Monica Plechero for her help with the tests of significance used in this paper. All errors are the sole responsibility of the author. 


\section{Introduction}

This paper introduces the first results of the project "Emerging trends in Asia: from cost-based producers to global suppliers of innovation: implications for industry growth in developed and developing countries”, funded by the Swedish Research Council. The general objective of this project is to understand the extent and scope of the globalization of innovation activities and discuss its implications for developed and developing countries. This general objective can be divided into the following specific objectives: a) to unfold global distribution of activities in the value chain of a selection of industries; b) to describe the changing role of particular regions in developing countries, specifically in China and India in the global value chain, c) to identify the critical elements supporting the transition from low-cost producers to innovators of firms located in those particular regions and in a specific industry ${ }^{\mathrm{i}}$ and d) to identify inter-regional differences in terms of the endowment of those factors. Among these factors we consider the level of technological competences, the linkages of the firm, the internationalization strategy of the firm and the regional innovation system in which the firms were located.

The two regions in the project are Pune in India and Great Beijing in China. In the project three industries are systematically compared: automotive (autoparts), software and green-biotech in both regions. Information was collected during 2008 and 2009 through a survey and semi-structured interviews with firms in Pune and Beijing. For the survey, we used the same questionnaire to collect information at firm level in the three industries and the two regions, which allows us to control for inter-industry differences (that is, differences between industries, even in the same region) as well as inter-regional differences (differences between regions in the same industry).

This paper mainly focuses on the organization and geography of interactions between firms and other organizations in two of the three industries: software and autoparts. The paper contributes to the most recent economic geography literature that argues that industries differ in their knowledge bases and that consequently one may expect that different industries show different patterns of local-global interactions. By systematically comparing two industries in two regions, our results show stronger differences between regions in the same industry than between industries in the same region thus pointing out to other factors explaining the geography of innovation in that particular industry rather than their knowledge bases.

The paper is structured as follows. First, the theoretical background of the paper is briefly introduced. Section 3 describes the two regions under study: Pune in India and Great Beijing in China. Section 4 presents the research design and methods. This is followed by the main findings. The paper in rounded up with some alternative explanations to the findings beyond differences in the knowledge base of the two studied industries. 


\section{Main theoretical framework}

It is generally accepted that innovation is socially embedded and that it is the result of continuous interactions and exchange of knowledge between organizations (Kline, S. and Rosenberg, N. 1986; Freeman, C. 1987; Lundvall, B.-A. 1992). For long, economic geographers have argued that due to the tacit nature of knowledge those interactions often take place at local level, that is, between organizations that are geographically close (Cooke, P. 1995; Storper, M. and Venables, A. 2004; Asheim, B. and Gertler, M. 2005; Boschma, R. 2005).

The role of geographical proximity has been challenged recently by empirical evidence suggesting that global linkages seem to be more important than local interactions in a variety of clusters (Hagedoorn, J. and Narula, R. 1996) or at least a very valuable complement to the local "buzz" (Bathelt, H., Malmberg, A. and Maskell, P. 2004; Gertler, M. S. and Levitte, Y. M. 2005; Gertler, M. 2008). They argue that rise of internet and the increase in the codification of knowledge may make face to face and inter-personal communication less necessary. Knowledge (codified) can be transferred across large geographical distances without the need of local interaction but it still requires a certain common understanding between the partners involved in the knowledge exchange for that knowledge to be useful for innovation. Relational proximity can link together actors that are geographically distant, thus enabling the transfer of knowledge even when geographical proximity is absent (Amin, A. and Cohendet, P. 2005; Gertler, M. 2008).

Most recent literature shows that both local and global interactions coexist in almost every cluster and industry (Giuliani, E., Bell, M. 2004; Giuliani, E., Pietrobelli, C. and Rabellotti, R. 2005; Giuliani, E., Rabelotti, R. and Van Dijk, M. P. 2005; Giuliani, E. 2007; Moodysson, J. 2008; Moodysson, J., Coenen, L. and Asheim, B. 2008) as both tacit and explicit knowledge are a crucial ingredients for innovation (Nightingale, P. 1998).

However there are significant differences between industries in the importance of local-global linkages for innovation. As some authors argue industries differ substantially in their knowledge bases (Pavitt, K. 1984; Asheim, B. and Coenen, L. 2005; Asheim, B. and Gertler, M. 2005; Moodysson, J., Coenen, L. et al. 2008; Martin, R. and Moodysson, J. 2010; Martin, R. and Moodysson, J. Forthcoming 2001; Blazek, J., Zizalova, P., Rumpel, P. and Skokan, K. Forthcoming 2011; Garman Johnsen, I. Forthcoming 2011; Gülcan, Y., Akgüngör, S. and Kustepeli, Y. Forthcoming 2011; Plum, O. and Hassink, R. Forthcoming 2011; Sotarauta, M. and Kosonen, K.-K. Forthcoming 2011; Tödtling, F., Lengaver, L. and Höglinger, C. Forthcoming 2011) and these differences have important implications in terms of the geographical spread of their knowledge-intensive activities (Laestadius, S. 1998; Asheim, B. and Gertler, M. 2005; Asheim, B., Coenen, L. and Vang, J. 2007). Industries dominated by synthetic knowledge bases will, in principle, display different patterns of knowledge sourcing within and across national borders than industries dominated by analytical or symbolic knowledge bases. 
This paper focuses mainly on two of the three industries considered in the project: software and autoparts. These two industries vary in terms of the nature of knowledge mainly used in their innovation process, their main drivers of technological change and their technological intensity.

The automotive firms knowledge base combines mechanical, electrical and transportation technologies (Wiig, H. and Herstad, S. 2009). In this respect, one could argue that their dominant knowledge base is synthetic. This is particularly true for the firms considered in this study, which are mainly suppliers of mechanical autoparts to the main automotive assemblers both in Beijing and in Pune. Software firms, on the other hand, are providers of specialized knowledge and technical solutions (Castellacci, F. 2008) which, in turn, is the result in many cases of substantial R\&D as well as a strong reliance on established process and protocols, similar to life sciences. Firms in this project are mainly software service providers that, for example, provide software for banking firms/services or for bio-technology processes. In this respect, we could consider this industry as dominated by analytic knowledge bases. We expect that the access to global value chains would happen less extensively and more gradually in industries or activities within those industries where knowledge is less codified (automotive design) than in others where knowledge is more readily codified (software).

This line of research has been recently complemented by a number of studies (see for example Tödtling et al. in this same issue) comparing the same industry in two different geographical locations. These later studies argue that, while the knowledge-bases are undoubtedly an important factor explaining differences in the geographical location of knowledge sources other factors -like the type of regional innovation systems in which the firms are located- should also be considered.

This paper relates more to this last stream of literature, extending the analysis to regions and industries in emerging economies. Hitherto the empirical evidence supporting the knowledge-based approach is based on evidence from developed countries. One of the research questions guiding this paper was to discuss if the arguments also hold for regions and industries in the developing world. Using firm-level data collected through a survey in 2008 followed by semi-structured interviews with firms in 2009-2010, this article systematically compares the geography of linkages of two industries (automotive and software) ${ }^{\text {ii }}$ between two regions, one in India (Pune) and one in China (Great Beijing). The purpose of the paper is to assess if inter-industrial differences are stronger than inter-regional differences in terms of knowledge sourcing, that is, if the differences between software and automotive firms are stronger than differences between firms located in Beijing and Pune. Following the literature on knowledge bases, we would expect this to be the case.

\section{Great Beijing and Pune}

The Great Beijing is considered to be the scientific and technological heart of China and thus the leading S\&T region in China in terms of both its research infrastructure and its innovation performance (Guan, J., Yam, R., Tang, E. and Lau, A. 2009) . In total, 71 
universities and 371 research institutes were located in Beijing at the end of 2003 (Chen, K., Kenney, M. 2005). These include some of Asia's best known universities and research institutions like the Chinese Academy of Sciences (CAS), Peking University and Tsinghua University. In 2005, CAS employed more than 37000 scientists and engineers, while in 2002 Peking University and Tsinghua University employed approximately 26000 scientists and technicians (Chen, K., Kenney, M. 2005). One of the most important IT science parks, the Zhingguancun Science Park (ZGC) is also located in Beijing in the Haidan district in close proximity to CAS, Peking University and Tsinghua University. Moreover, it is estimated that around $400 \mathrm{R} \& \mathrm{D}$ centers from multinational corporations are located in Beijing and Shanghai, representing approximately 50\% of all R\&D centers located in China in 2005-2006 (China Knowledge 2009).

This large concentration of research institutes and universities in Beijing explains the high performance of the region in terms of innovation. With regards to the latter, almost $40 \%$ of S\&T initiatives in mainland China are performed in Beijing (Guan, J., Yam, R. et al. 2009). In 2000, a quarter of the government S\&T funds ended up in institutions located in Beijing and about $18 \%$ of all patents were also granted to Beijing (Chen, K., Kenney, M. 2005). Furthermore, it is considered as the most active municipality in terms of technology transfer from university to industry (Hong, W. 2008).

Industrially, Beijing has a specialization in high-tech industries. In recent years, approximately between one fourth and two thirds of the city's total industrial added value has been attributable to high-tech business (Chen, K., Kenney, M. 2005; Guan, J., Yam, R. et al. 2009).

Due to the raising costs in Beijing city, some of the innovation and production activities that previously were located in Beijing have moved to the neighboring provinces of Tianjin and Hebei. Jointly Beijing, Tianjin and Hebei form one of the largest city-regions or megalopolis in China - the so-called Jing-Jin-Ji region (TaoFang, Y. 2005). This is the region considered for this paperiii .

On the other hand, Pune (India) is increasingly attracting the attention of academics as a growing research and innovation center in India, gradually catching up with Bangalore. Its proximity to Mumbai as well as the combined presence of foreign companies, research labs and good education and research institutions is considered to be attractive for multinational companies to establish their production and, more recently, $R \& D$ activities in Pune. In 2008, it was estimated that around $600 \mathrm{R} \& \mathrm{D}$ centers of multinational corporations were established in India. Of those, approximately a hundred were set in Pune, and around 312 in Bangalore ((Zinnov 2009).

In 2007 the Pune region had 9500 manufactured units ${ }^{\text {iv }}$ in contrast with the 4529 that the region hosted in 1985, showing a continuous growth in particular in recent years. The majority of firms in the area are micro (4790), small and medium firms (4600), while large firms are few (1.15\% of the total units) although they account for $15 \%$ of the total employment (Mccia 2009). Pune is characterized by a strong presence of firms in the IT, auto-component, chemical and pharmaceutical industries. 
Biotechnology is also represented nowadays as an emerging sector in the local cluster (Basant R., C., P. 2007). The automotive industry, one of the oldest in Pune, had an expansion period between 1960 and 1990 and at the beginning of 2000. Between 2001 and 2005 more than 5000 SMEs manufacturing auto-related product were registered with the local District Industries Centre. The Pune region also has a long tradition in agro-processing and nowadays the food-processing industry is becoming a new important hub. Around 1700 firms and a total of 30000 employees belong to this last subsector (Mccia 2008). The IT industry and the biotech industry represent the two new drivers of the Pune Economy. For the IT industry in the area it is possible to count over 1000 IT and ITES companies and about 200 IT Parks (Mccia 2009).

The Pune region, like Bangalore, offers a large numbers of educational facilities such as important academic institutions and technology development centers (e.g. Tata Research Development Center) able to maintain a variety of linkages with the local industry (Basant R., C., P. 2007). The city of Pune counts 6 universities and 600 functional colleges and PG departments (Mccia 2008). The presence of a certain number of educational institutions in Pune allows good access to skilled labor, training and R\&D facilities devoted to the needs of the local market. Technical and engineering education aimed at training, in particular, the employees in the ICT and auto-component industries in the area is ensured by the presence of engineering and professional colleges such as the Pimpri Chinchwad College of Engineering and the Modern Education Society's college of Engineering. The colleges sustain the current growth of local expertise in the field of engineering services and design. Other institutions are relevant for training and research in biotechnology and pharma such as the Indian Drugs Research, the Agharkar Research Institute and the National Chemical Laboratory $(\mathrm{NCL})^{\mathrm{v}}$.

In sum, both Pune and the Great Beijing can be considered as knowledge hubs in their respective countries, increasing significantly their international role both as recipients and transmitters of knowledge-intensive activities world-wide.

\section{Method}

The empirical analysis is based on firm-level primary data collected through a survey in the Pune (India) and Great Beijing (China) regions in 2008 in two industries: software and autoparts.

\subsection{The sample}

For the Pune area, we used a random sample out of different databases bought from Indian industry associations. The survey was conducted using face to face interviews, followed up by phone calls when necessary. For small and medium enterprises, in most cases the interviewee was the owner-manager, while in larger firms the interviewee was usually the R\&D Head or his/her deputy. The response rate was around $40 \%$. 
In the Great Beijing area, we used a sample extracted from different databases from a market research company (Sinotrast) as well as from a software testing center (CSTC) for the software industry only. The survey was conducted mainly by phone with an average response rate of $20 \%$. The firms from the CSTC database were contacted by email. The response rate in this last case was around 7\%. Few interviews were conducted face to face. Like in Pune, the interviewee was mainly the owner for SMEs and the R\&D managers for large firms ${ }^{\mathrm{vi}}$. In both samples we conducted a test of nonresponse to assess if the sample was representative, which it was in both regions.

The survey targeted firms in three sectors in both regions: automotive component, green-biotech and software. In total, 1087 questionnaires were collected. $42.59 \%$ of the sample consisted of firms in the automotive components sector, $38.55 \%$ in the software sector and $18.86 \%$ in the green-biotech sector. The data for the greenbiotech was problematic ${ }^{\mathrm{vii}}$, so it was excluded from the analysis in this paper.

Table 1. Firms sample divided by region and industry

\begin{tabular}{lccc} 
Sector & \multicolumn{3}{c}{ Region } \\
\hline Automotive components & $190(41.04 \%)$ & $273(58.96 \%)$ & $463(100 \%)$ \\
Software & $198(47.26 \%)$ & $221(52.74 \%)$ & $419(100 \%)$ \\
\hline Total & $388(46.85 \%)$ & $494(59.66 \%)$ & $882(100 \%)$
\end{tabular}

In G. Beijing most of the firms are standalone companies (single plant firms) while in Pune it is possible to find both single plants as well as subsidiaries of multinationals, both for the automotive as well as for the software industry as table 2 shows.

Table 2. Distribution of firms by type of unit

\begin{tabular}{|c|c|c|c|c|}
\hline & $\begin{array}{c}\text { Companies } \\
\text { per category* }\end{array}$ & & $\begin{array}{l}\text { Companies } \\
\text { distribution** }\end{array}$ & \\
\hline & G. BEIJING & PUNE & G.BEIJING & PUNE \\
\hline \multicolumn{5}{|l|}{ Automotive Components } \\
\hline A single plant firm & 147 & 153 & $77,37 \%$ & $56,25 \%$ \\
\hline The head office of an entreprise group & 0 & 42 & $0,00 \%$ & $15,44 \%$ \\
\hline A subsidiary of an entreprise group & 43 & 77 & $22,63 \%$ & $28,31 \%$ \\
\hline TOTAL & 190 & 272 & $100,00 \%$ & $100,00 \%$ \\
\hline \multicolumn{5}{|l|}{ Software } \\
\hline A single plant firm & 164 & 87 & $82,83 \%$ & $39,37 \%$ \\
\hline The head office of an entreprise group & 1 & 10 & $0,51 \%$ & $4,52 \%$ \\
\hline A subsidiary of an entreprise group & 33 & 124 & $16,67 \%$ & $56,11 \%$ \\
\hline $\begin{array}{ll}\text { TOTAL } \\
\end{array}$ & 198 & 221 & $100,00 \%$ & $100,00 \%$ \\
\hline
\end{tabular}

In terms of size, the sample covers all sizes of companies. Although SMEs are quite predominant, large firms are more common in the automotive in G. Beijing than in Pune 
while in the software industry there are a greater proportion of large firms in Pune rather than in G. Beijing, which is coherent with the proportion of MNCs and subsidiaries of MNCs in the software industry in Pune.

Table 3. Distribution of companies by size

\begin{tabular}{|c|c|c|c|c|}
\hline & \multicolumn{2}{|c|}{ Companies per category* } & \multicolumn{2}{|c|}{$\begin{array}{c}\text { Companies } \\
\text { distribution** }\end{array}$} \\
\hline & G. BEIJING & PUNE & G. BEIJING & PUNE \\
\hline \multicolumn{5}{|l|}{ Automotive Components } \\
\hline small: 1-49 & 85 & 170 & $44,74 \%$ & $62,27 \%$ \\
\hline medium: 50-249 & 75 & 75 & $39,47 \%$ & $27,47 \%$ \\
\hline large: 250-more than 2500 & 30 & 28 & $15,79 \%$ & $10,26 \%$ \\
\hline TOTAL & 190 & 273 & $100,00 \%$ & $100,00 \%$ \\
\hline \multicolumn{5}{|l|}{ Software } \\
\hline small: 1-49 & 88 & 88 & $44,44 \%$ & $39,82 \%$ \\
\hline medium: 50-249 & 87 & 85 & $43,94 \%$ & $38,46 \%$ \\
\hline large: 250 -more than 2500 & 23 & 48 & $11,62 \%$ & $21,72 \%$ \\
\hline TOTAL & 198 & 221 & $100,00 \%$ & $100,00 \%$ \\
\hline
\end{tabular}

The survey inquired firms about their innovation activities, internationalization strategies, competences and local-global linkages. This specific paper focuses in particular on the linkages for innovation.

\subsection{Measurement of linkages}

To capture the firm's type, nature and geographical location of linkages in particular in relation to firm's innovation activities, firms were asked in the survey specific questions about:

1) Which actors where considered important source of technology of knowledge for the

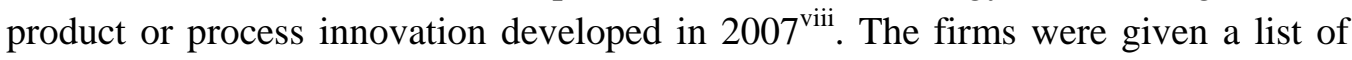
sources and were asked to select the sources that were important for the development of that innovation and leave the option blank if that source was not important.

2) In case it had been important, the firms were then asked to indicate if that source was mainly local, domestic or international.

In the next section I will present some descriptive analysis of the sample in the two regions related to those specific questions. The specific questions to answer in the study require comparing the distributions of the linkages across the two regions and the different sectors. The idea is to isolate the differences and single out the equalities to have a clearer picture of the commonalities and of the specificities of each regional or sectoral system. In this paper, I undertake this analysis descriptively, portraying the two 
regions without entering the discussion of causal forces or co-founding factors. Different tests are run to compare the distribution between sectors in the same region and between regions in the same sector and identify differences that are significant at $1 \%, 5 \%$ or $10 \%$ : t-tests for the means, pr-tests to compare two different proportions, and Chi2 tests when there is a need to see if the distributions between different types of linkages was similar or not between the two regions or sectors. Differences have been tested in four different ways. Test 1 refers to differences across countries. It compares the distribution of responses of the firms located in Pune and in Beijing, independently of the industry. Test 2 indicates if there exist significant differences across industries in the whole sample. It compares the distribution of responses of the firms in the autoparts industry to those in software, independently of where they are located. Test 3 analyses the significance of the differences between industries in Beijing and Test 4 refers to the differences between industries in Pune. The results are discussed next.

\section{Findings}

\subsection{Composition of the networks: actors}

As Table 4 shows there are significant differences in the importance that firms in Pune and Great Beijing attribute to different sources of knowledge, in particular employees, suppliers, universities and Government. These differences are significant at $1 \%$ level. Clearly, a larger proportion of firms located in G. Beijing consider employees, suppliers, universities and government to be more important as a source of technology and knowledge than firms located in Pune.

Comparing the two sectors, there are significant differences between the network of firms in the automotive industry and the software industry, particularly with regards to the importance of returnees, suppliers, clients, competitors, universities and government. Suppliers and clients are significantly more important for the automotive industry while returnees, competitors, universities and government are clearly more important for the software industry.

In Beijing, one can observe significant differences between the automotive and the software industry only when it comes to suppliers and government. Suppliers are more important for automotive firms while the government is considered to be a more relevant source of knowledge by the software firms. Indeed the Government plays a very important role in the software industry in G. Beijing through public procurement but it also plays a more direct role funding laboratories for spin-off software firms which develop software applications that are being directly used for defense, as the interviews suggested ${ }^{\text {ix }}$. Nevertheless in general, both industries behave in a quite similar way when it comes to the sources of knowledge and technology for innovation. In Pune, on the other hand, there are more differences between the two industries, with returnees, universities and consultants being more important for software than for auto and clients and competitors being significantly more important for auto than for software. 
Table 4. Importance of sources of technology and knowledge for product or process innovation developed in 2007

Sector

Distribution between countries Distribution within countries

\begin{tabular}{|c|c|c|c|c|c|c|c|c|c|c|c|c|c|}
\hline Type of sources AUTOMOTIVE & China & India & Tot & China & India & Tot & China & India & Tot & Test 1 & Test 2 & Test 3 & Test 4 \\
\hline Existing employees (excluding returnees) & 139 & 104 & 243 & 57,2 & 42,8 & 100 & 73,16 & 38,1 & 52,48 & $7.43^{* * *}$ & $-1.71^{*}$ & $-2.04 * *$ & 0.23 \\
\hline Returnees from abroad & 29 & 11 & 40 & 72,5 & 27,5 & 100 & 15,26 & 4,03 & 8,64 & $4.23^{* * *}$ & $-7.03 * * *$ & $-1.75^{*}$ & $-7.97 * * *$ \\
\hline Suppliers & 131 & 121 & 252 & 51,98 & 48,02 & 100 & 68,95 & 44,32 & 54,43 & $5.23^{* * *}$ & $3.76^{* * *}$ & $6.33^{* * *}$ & -0.41 \\
\hline Clients & 153 & 246 & 399 & 38,35 & 61,65 & 100 & 80,53 & 90,11 & 86,18 & $-2.94 * * *$ & $5.71^{* * *}$ & 1.02 & $6.76^{* * *}$ \\
\hline Competitors & 113 & 147 & 260 & 43,46 & 56,54 & 100 & 59,47 & 53,85 & 56,16 & 1.20 & $2.78^{* * *}$ & 0.28 & $3.81^{* * *}$ \\
\hline Consultancy companies & 38 & 34 & 72 & 52,78 & 47,22 & 100 & 20 & 12,45 & 15,55 & $2.20^{* *}$ & $-4.70^{* *}$ & 1.26 & $-7.21^{* * *}$ \\
\hline Universities & 47 & 2 & 49 & 95,92 & 4,08 & 100 & 24,74 & 0,73 & 10,58 & $8.26^{* * *}$ & $-5.10 * * *$ & $-1.76^{*}$ & $-6.12^{* * *}$ \\
\hline Government & 65 & 21 & 86 & 75,58 & 24,42 & 100 & 34,21 & 7,69 & 18,57 & $7.22^{* * *}$ & $-4.14^{* * *}$ & $-2.95 * * *$ & $-2.28^{* *}$ \\
\hline Other & 2 & 0 & 2 & 100 & 0 & 100 & 1,05 & 0 & 0,43 & $1.70^{*}$ & $-1,27$ & 0.62 & $-2.23 * *$ \\
\hline
\end{tabular}

Tot

Distribution between countries Distribution within countries

\begin{tabular}{|c|c|c|c|c|c|c|c|c|c|c|c|c|c|}
\hline Type of sources ICT & China & India & Tot & China & India & Tot & China & India & Tot & Test 1 & Test 2 & Test 3 & Test 4 \\
\hline Existing employees (excluding returnees) & 162 & 82 & 244 & 66,39 & 33,61 & 100 & 81,82 & 37,1 & 58,23 & $9.27^{* * *}$ & $-1.71^{*}$ & $-2.04 * *$ & 0.23 \\
\hline Returnees from abroad & 44 & 67 & 111 & 39,64 & 60,36 & 100 & 22,22 & 30,32 & 26,49 & $-1.87^{*}$ & $-7.03^{* * *}$ & $-1.75^{*}$ & $-7.97^{* * *}$ \\
\hline Suppliers & 73 & 102 & 175 & 41,71 & 58,29 & 100 & 36,87 & 46,15 & 41,77 & $-1.92^{*}$ & $3.76^{* * *}$ & $6.33^{* * *}$ & -0.41 \\
\hline Clients & 151 & 144 & 295 & 51,19 & 48,81 & 100 & 76,26 & 65,16 & 70,41 & $2.49 * *$ & $5.71^{* * *}$ & 1.02 & $6.76^{* * *}$ \\
\hline Competitors & 115 & 81 & 196 & 58,67 & 41,33 & 100 & 58,08 & 36,65 & 46,78 & $4.39^{* * *}$ & $2.78^{* *}$ & 0.28 & $3.81^{* * *}$ \\
\hline Consultancy companies & 30 & 90 & 120 & 25 & 75 & 100 & 15,15 & 40,72 & 28,64 & $-5.78^{* * *}$ & $-4.70^{* *}$ & 1.26 & $-7.21^{* * *}$ \\
\hline Universities & 65 & 33 & 98 & 66,33 & 33,67 & 100 & 32,83 & 14,93 & 23,39 & $4.32^{* * *}$ & $-5.10^{* * *}$ & $-1.76^{*}$ & $-6.12^{* * *}$ \\
\hline Government & 97 & 31 & 128 & 75,78 & 24,22 & 100 & 48,99 & 14,03 & 30,55 & $7.76^{* * *}$ & $-4.14^{* * *}$ & $-2.95 * * *$ & $-2.28^{* *}$ \\
\hline Other & 1 & 4 & 5 & 20 & 80 & 100 & 0,51 & 1,81 & 1,19 & -1.23 & $-1,27$ & 0.62 & $-2.23 * *$ \\
\hline
\end{tabular}

Tot

47,26

100

100

$10 \% * 1$

Test 2. Test between 2 the sectors, together Pune \& g. beijing. PR TEST (test of proportion). P-value: Significant level: $1 \%{ }^{* * *} ; 5 \% * * ; 10 \% *$ )

Test 3. Test between sectors in G. Beijing. PR TEST (test of proportion). P-value: Significant level: $1 \%{ }^{* * *} ; 5 \% * * ; 10 \% *$ )

Test 4. Test between sectors in Pune. PR TEST (test of proportion). P-value: Significant level: $1 \%{ }^{* * * ;} 5 \%{ }^{* *} ; 10 \% *$ ) 
Table 5. Geography of sources of technology and knowledge for product or process innovation developed in 2007

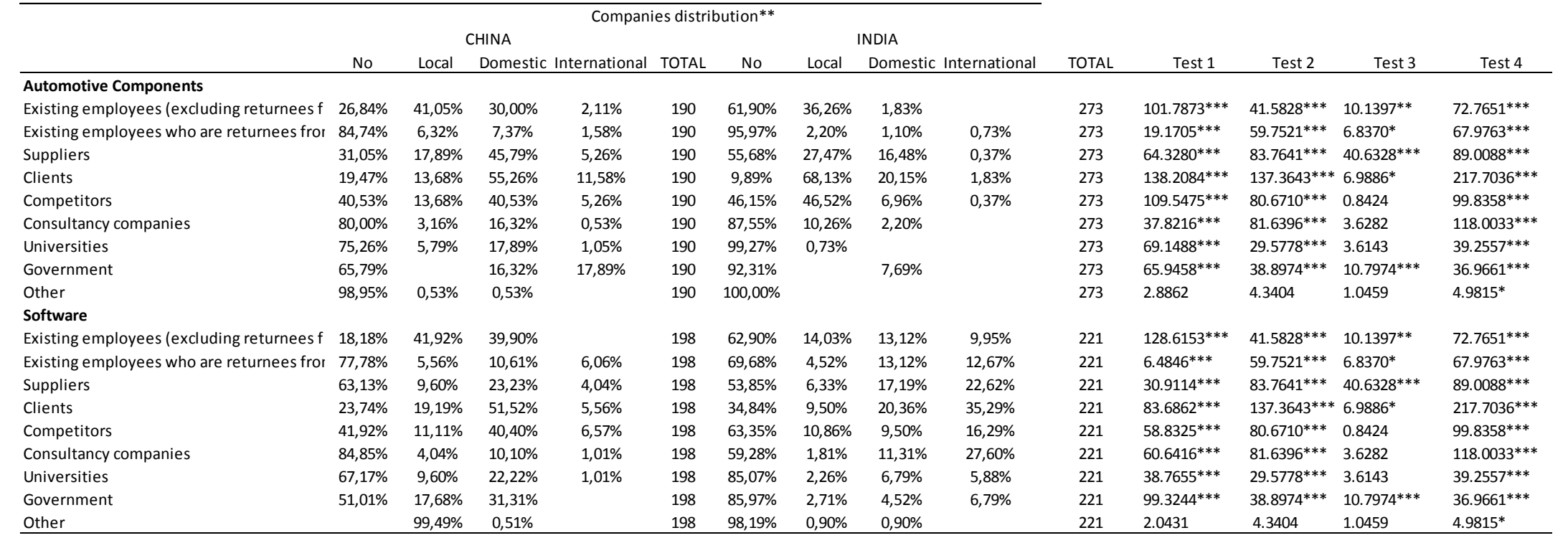

Test1. Comparison of distribution across countries. Chi2 (test of disjoint distribution). P-value: Significant level: $1 \% * * * ; 5 \% * * ; 10 \% *$ )

Test 2. Test between 2 the sectors, together Pune \& g. beijing. Chi2 (test of disjoint distribution). P-value: Significant level: $1 \% * * * ; 5 \% * ; 10 \% *$ )

Test 3. Test between sectors in G. Beijing. Chi2 (test of disjoint distribution). P-value: Significant level: $1 \%{ }^{* * *} ; 5 \% * * ; 10 \% *$ )

Test 4. Test between sectors in Pune. Chi2 (test of disjoint distribution). P-value: Significant level: $1 \%{ }^{* * * ;}, 5 \%{ }^{* *} ; 10 \%{ }^{*}$ ) 


\subsection{Geography of the linkages}

Table 5 presents the main results for the geography of the linkages, distinguishing between local, domestic or international linkages. The tests refer to differences in the distribution of each source between local, domestic and international.

Firms in Beijing and Pune show significantly different patterns in the geographical distribution of their main sources for innovation (Test 1), and this applies to all the considered sources or partners. All the $\mathrm{Chi}^{2}$ are significant at $1 \%$. In general firms in G. Beijing rely much more on domestic sources than firms in Pune, independently of the sector.

There are also persistent and significant differences between industries as Test 2 shows. The geography of the networks of the automotive and the software industry is significantly different for all sources considered. This does not mean that they differ in which sources are important, but that they differ in the geographical location of those sources. Looking also at the percentages, one can easily observe that firms in Pune use more intensively the local or international network than G. Beijing.

These aggregated differences can be better understood when looking at the intraregional differences. While the two sectors in G. Beijing rely mainly on domestic sources, in Pune there is a clear distinction between the auto sector which relies mainly on local sources or none at all- and the software sector which relies mainly on international sources -or none at all $^{\mathrm{x}}$. It is these differences that are reflected in the inter-industry tests. So, what can be observed are not differences between industries that are consistent in different regions, but regional differences. What is that makes Pune firms behave in a different way than G. Beijing firms even in the same industry?

\section{Discussion - different linkages, different strategies and markets?}

Considering together the composition of the network as well as its geography, one can observe the there are significant differences in the composition and geography of the network in both industries between Pune and Great Beijing. While the automotive industry in G. Beijing relies mainly on domestic sources, Pune automotive firms prime local interactions. And while software firms in Beijing rely also on domestic sources, Pune-based software firms have more international linkages. In G. Beijing a strong preference for domestic links is observed, independently of the industry while Pune would be a very good example of a localglobal regional innovation system with certain sectors showing a tendency towards local or international linkages. These results are interesting as compared to those by Tödtling et al. in this same special issue. Both Pune and Beijing can be considered as regional innovation systems with a thick institutional infrastructure, with a large number of industrial support institutions from centers for vocational training to testing facilities accessible to all firms within the region (Cooke, P. 1992; Tödtling, F. and Trippl, M. 2005),. Nevertheless, both the organization as well as the geography of the networks differ significantly, with Pune firms showing stronger local-global linkages than Beijing, where firms are mainly targeting domestic markets. 
One of the key aspects to take into account when explaining the differences in networking of Pune vs. G. Beijing firms is the strategy of the firm, particularly with reference to the software industry which, in turn, reflects different trajectories in the emergence and development of the regional innovation system. As it can be seen in the next Table 6, while Chinese software firms mainly target the domestic market, the Indian software firms have, in general, a very international profile.

Table 6. Main market

\begin{tabular}{|c|c|c|}
\hline & \multicolumn{2}{|c|}{ Companies distribution* } \\
\hline & G. BEIJING & PUNE \\
\hline \multicolumn{3}{|l|}{ Automotive Components } \\
\hline Domestic market & $86,99 \%$ & $95,57 \%$ \\
\hline Foreign market & $13,01 \%$ & $4,43 \%$ \\
\hline TOTAL & $100,00 \%$ & $100,00 \%$ \\
\hline \multicolumn{3}{|l|}{ Software } \\
\hline Domestic market & $90,02 \%$ & $51,44 \%$ \\
\hline Foreign market & $9,98 \%$ & $48,56 \%$ \\
\hline TOTAL & $100,00 \%$ & $100,00 \%$ \\
\hline
\end{tabular}

A closer look at the regional innovation system of Pune and Great Beijing may provide some clues on the relationship between the market and the geography of the network. Pune's has a strong specialization in the automotive industry, and more particular in engineering, that dates back to the mid sixties ${ }^{\mathrm{xi}}$. As compared to other parts of India, Pune has been attracting mainly European automobile MNCs, who established their manufacturing facilities and later their $R \& D$ (applied research) facilities in Pune to benefit from the proximity to Mumbai as well as to tap on the local pool of specialized engineers. Mercedes-Benz, BMW, Volkswagen, Scania are some examples of firms with subsidiaries in Pune. This strong specialization of the region in the automotive industry may explain (at least partly) the strength of the local linkages. In comparison, despite the great number of automotive companies established there, G. Beijing is not considered to be the hub of the automotive industry in China, which is mainly located around Shanghai. The autopart companies interviewed in the project were all suppliers of the auto assembling companies that were located mainly in Shanghai or in other lower-cost parts of China. In both cases (Pune and Beijing) the main market is domestic, that is, firms, particularly MNC firms are established in G. Beijing or Pune to access the local market.

Software firms in Pune are clearly targeting the international market. Most of the interviewed firms started to work as subcontractors of large MNC companies. Most of them are specialized in very specific market niches (like for example software for stock-markets, or software for automotive design ${ }^{\text {xii }}$ ) that they commercialize world-wide. In some cases, the firm had such specialized knowledge that it was acquired by a MNC company, then turning into a MNC itself ${ }^{\text {xiii }}$. In sharp contrast with the Pune firms, Beijing-based software firms are clearly targeting the domestic market. One of the reasons for this is that the domestic IT 
market is growing dramatically over the last year ${ }^{\mathrm{xiv}}$. Even some of the few companies that started targeting the international markets, have turned into the domestic market after their international business volume decreased significantly during the crisis ${ }^{\mathrm{xv}}$. As it was repeated in most of the interviews Chinese software firms want to position themselves in the rapidly growing domestic market, where they have the advantage of the language and the contacts, and only when they are consolidated as leaders in the domestic market, move to the international markets. Their network is mainly domestic also reflecting this market orientation: clients are domestic, as well as the most important partners.

So, while knowledge bases may be one important factor explaining differences in the geography of knowledge networks, it is not a sufficient one. As our evidence suggests, the same industry in two countries/regions with similar level of development, can behave in a different way with regards to both the organization as well as the geography of the network, even when they are dominated by the sane knowledge base. Looking at the strategy of the firms, the market and the development of the RIS can provide some additional explanations to the different geographical spread of their knowledge networks but other factors may also be crucial to explain differences. More systematic comparison of the same industry across different regions around the world may provide new insights on the determinants of the geography of sourcing in different industries. A deeper look at the type of activities that are being conducted by the firms in Pune and Beijing in the value chain may also provide some new insights into the reasons of the observed differences between Pune and Beijing.

A final word on the next steps of the project. The results presented represent only a small fraction of the analysis that we are currently conducting with the data collected in the project. Among other issues, we are studying the impact of the geography of the networks on the degree of novelty of innovations (Chaminade, C. and Plechero, M. 2010) or the relationship between competences and modes of globalization of innovation ((Plechero, $\mathrm{M}$. and Chaminade, C. 2010). Further work will include a deeper analysis of the specialization of Pune and Beijing firms in the global value chain and their implications for the geography of knowledge sources and the extension of the analysis to firms in other European countries (like Sweden and Norway). 


\section{Table 7. Summary of main results}

Table 7a. Summary of findings. Differences in the geography and organization of knowledge sourcing in G. Beijing and Pune

\begin{tabular}{|l|l|l|l|l|}
\hline & Inter-regional differences & Inter-industry differences & $\begin{array}{l}\text { Intra-regional difference G. } \\
\text { Beijing }\end{array}$ & $\begin{array}{l}\text { Intra-regional difference } \\
\text { Pune }\end{array}$ \\
\hline Composition of the network & $\begin{array}{l}\text { Pune and g. Beijing differ } \\
\text { significantly on the } \\
\text { importance attributed to } \\
\text { employees, suppliers, clients } \\
\text { universities and government } \\
\text { for AUTO and existing } \\
\text { employees, competitors, } \\
\text { consultants, universities and } \\
\text { government for SOFT }\end{array}$ & $\begin{array}{l}\text { SOFT and AUTO differ } \\
\text { significantly on the } \\
\text { importance of all sources, } \\
\text { with the exception of } \\
\text { existing employees. }\end{array}$ & $\begin{array}{l}\text { SOFT and AUTO in G. Beijing } \\
\text { differ only in the importance } \\
\text { attributed to suppliers (more } \\
\text { important in auto) and } \\
\text { government (more } \\
\text { important in software) }\end{array}$ & $\begin{array}{l}\text { SOFT and AUTO in Pune } \\
\text { differ in returnees, clients, } \\
\text { competitors, consultancy } \\
\text { and universities }\end{array}$ \\
\hline Geography of the network & $\begin{array}{l}\text { Significant. Pune more local- } \\
\text { global while G. Beijing more } \\
\text { domestic }\end{array}$ & $\begin{array}{l}\text { Significant, but more due to } \\
\text { variety in Pune's industries } \\
\text { than in Beijing }\end{array}$ & $\begin{array}{l}\text { Not-significant. Both } \\
\text { industries rely mainly on } \\
\text { domestic sources }\end{array}$ & $\begin{array}{l}\text { Significant. Auto relies more } \\
\text { on local sources and } \\
\text { software on international } \\
\text { sources }\end{array}$ \\
\hline
\end{tabular}

Table 7b. Detailed account of intra regional differences

\begin{tabular}{|c|c|c|c|c|}
\hline & \multicolumn{2}{|c|}{ Automotive (Autoparts) } & \multicolumn{2}{|c|}{ Software } \\
\hline & Pune & G. Beijing & Pune & G. Beijing \\
\hline Main market & Domestic & Domestic & International & Domestic \\
\hline Most common source & $\begin{array}{l}\text { Clients followed by } \\
\text { competitors }\end{array}$ & $\begin{array}{l}\text { Clients followed by } \\
\text { employees }\end{array}$ & Clients followed by suppliers & $\begin{array}{l}\text { Employees followed by } \\
\text { clients }\end{array}$ \\
\hline Composition of the network & $\begin{array}{l}\text { Clients and competitors } \\
\text { more important in auto in } \\
\text { Pune than in software in } \\
\text { Pune }\end{array}$ & $\begin{array}{l}\text { Suppliers, competitors and } \\
\text { consultancy companies are } \\
\text { more important for auto } \\
\text { than for software }\end{array}$ & $\begin{array}{l}\text { Returnees, Consultancy, } \\
\text { universities more important } \\
\text { in software than in auto in } \\
\text { Pune }\end{array}$ & $\begin{array}{l}\text { Universities and } \\
\text { Government are very } \\
\text { important partners as } \\
\text { compared to auto-Beijing }\end{array}$ \\
\hline Geography of network: & $\begin{array}{l}\text { Mainly relying on local } \\
\text { sources }\end{array}$ & $\begin{array}{l}\text { Mainly relying on domestic } \\
\text { sources }\end{array}$ & $\begin{array}{l}\text { Mainly relying on } \\
\text { international sources }\end{array}$ & $\begin{array}{l}\text { Mainly relying on domestic } \\
\text { sources }\end{array}$ \\
\hline
\end{tabular}




\section{References}

Amin, A. and P. Cohendet (2005). "Geographies of Knowledge Formation in Firms." Industry and Innovation 12(4): 465-486.

Asheim, B. and L. Coenen (2005). "Knowledge bases and regional innovation systems: Comparing Nordic clusters." Research Policy 34(8): 1173.

Asheim, B., L. Coenen and J. Vang (2007). "Face-to-face, buzz, and knowledge bases: sociospatial implications for learning, innovation, and innovation policy." Environment and Planning C: Government and Policy 25(5): 655 - 670.

Asheim, B. and M. Gertler (2005). The geography of innovation: regional innovation systems. The Oxford Handbook of Innovation. J. FAGERBERG, D. MOWERY and R. NELSON. Oxford, OUP: 291-317.

Basant R., C., P. (2007). "Role of Educational and R\&D Institutions in City Clusters: An Exploratory Study of Bangalore and Pune Regions in India." World Development 35(6): 037-1055.

Bathelt, H., A. Malmberg and P. Maskell (2004). "Clusters and knowledge: local buzz, global pipelines and the process of knowledge creation." Progress in Human Geography 28(1): 31-56.

Blazek, J., P. Zizalova, P. Rumpel and K. Skokan (Forthcoming 2011). "where does the knowledge for knowledge intensive industries come from? the case of biotech in Prague and ICT in Ostrava."

Boschma, R. (2005). "Proximity and innovation: a critical assesment." $\underline{\text { Regional Studies }}$ 39(1): 61-74.

Castellacci, F. (2008). "Technological paradigms, regimes and trajectories: Manufacturing and service industries in a new taxonomy of sectoral patterns of innovation." Research Policy 37(6-7): 978-994.

Chaminade, C. and M. Plechero (2010). From new to the firm to new to the world. Effect of geographical proximity and technological capabilities on the degree of novelty in emerging economies CIRCLE electronic working papers 2010/12. Lund, CIRCLE.

Chen, K., Kenney, M. (2005). Universities/Research Institutes and Regional Innovation Systems: The Cases of Beijing and Shenzhen. "Universities as Drivers of the Urban Economies in Asia.

China Knowledge. (2009). "China Education and R\&D system." Retrieved March 2010, from

http://www.chinaknowledge.com/Business/CBGdetails.aspx?subchap=1\&content=8\# RDInChina.

Cooke, P. (1992). "Regional innovation systems: competitive regulation in the new Europe." Geoforum 23(3): 365-382.

Cooke, P. (1995). The rise of the rustbelt, Palgrave Macmillan.

Freeman, C. (1987). Technology policy and economic performance: lessons from Japan. London, Pinter.

Garman Johnsen, I. (Forthcoming 2011). "Constructing regional advantage in Oslo, Norway: The case of the animation industry." European Planning Studies.

Gertler, M. (2008). "8. Buzz Without Being There? Communities of Practice in Context." Community, Economic Creativity, and Organization 1(9): 203-227.

Gertler, M.S. and Y.M. Levitte (2005). "Local Nodes in Global Networks: The Geography of Knowledge Flows in Biotechnology Innovation." Industry and Innovation 12(4): 487507. 
Giuliani, E. (2007). "The selective nature of knowledge networks in clusters: evidence from the wine industry." Journal of Economic Geography 7(2): 139.

Giuliani, E., Bell, M. (2004). When micro shapes the meso: Learning networks in a Chilean wine cluster. SPRU Paper No. 115.

Giuliani, E., C. Pietrobelli and R. Rabellotti (2005). "Upgrading in Global Value Chains: Lessons from Latin American Clusters." World Development 33(4): 549-573.

Giuliani, E., R. Rabelotti and M.P. Van Dijk (2005). Clusters facing competition: the importance of external linkages. Aldershot and Burlington, Ashgate Publishing.

Guan, J., R. Yam, E. Tang and A. Lau (2009). "Innovation strategy and performance during economic transition: evidences in Beijing, China." Research Policy 38(5): 802-812.

Gülcan, Y., S. Akgüngör and Y. Kustepeli (Forthcoming 2011). "Knowledge generation and innovativeness in Turkish textile industry: comparison of Istambul and Denizli." European Planning Studies.

Hagedoorn, J. and R. Narula (1996). "Choosing Organizational Modes of Strategic Technology Partnering: International and Sectoral Differences." Journal of International Business Studies 27(2).

Hong, W. (2008). "Decline of the center: The decentralizing process of knowledge transfer of Chinese universities from 1985 to 2004." Research Policy 37(4): 580-595.

Kline, S. and N. Rosenberg (1986). An overview of innovation. The positive sum strategy. L. a. ROSENBERG. Washington D:C:, National Academy of Sciences: 289.

Laestadius, S. (1998). "Technology level, knowledge formation and industrial competence in paper manufacturing." Microfoundations of economic growth. A Schumpeterian perspective, The University of Michigan Press, Ann Arbor: 212-226.

Lundvall, B.-A., Ed. (1992). National systems of innovation. Towards a theory of innovation and interactive learning. Londres, Pinter.

Martin, R. and J. Moodysson (2010). Innovation in symbolic industries: the geography and organisation of knowledge sourcing. CIRCLE Electronic Working Papers 2010/07

Martin, R. and J. Moodysson (Forthcoming 2001). Innovation in symbolic industries: the geography and organisation of knowledge sourcing. European Planning studies

Mccia (2008). Profile and analysis of PUNE Manufacturing Inc. An Intelligence report on Growth of pune Industries. I. a. A. Mahratta Chamber of Commerce.

Mccia (2009). IT Directory. I. a. A. Mahratta Chamber of Commerce.

Moodysson, J. (2008). "Principles and Practices of Knowledge Creation: On the Organization of" Buzz" and" Pipelines" in Life Science Communities." Economic Geography 84(4): 449-469.

Moodysson, J., L. Coenen and B. Asheim (2008). "Explaining spatial patterns of innovation: analytical and synthetic modes of knowledge creation in the Medicon Valley lifescience cluster." Environment and Planning A 40(5): 1040-1056.

Nightingale, P. (1998). "A cognitive model of innovation." Research Policy 27(7): 689-709.

Pavitt, K. (1984). "Sectoral patterns of technical change: towards a taxonomy and a theory." Research Policy 13(6): 343-373.

Plechero, M. and C. Chaminade (2010). Different competences, different modes in the globalization of innovation? A comparative study of the Pune and Beijing regions CIRCLE electronic working papers 2010/03. Lund, CIRCLE.

Plum, O. and R. Hassink (Forthcoming 2011). "On the nature and geography of innovation and interactive learning: a case study of the biotechnology industry in the Aachan Technology Region, Germany." European Planning Studies. 
Sotarauta, M. and K.-K. Kosonen (Forthcoming 2011). "Digital or local buss, global or national pipelines - do knowledge bases matter?" European Planning Studies.

Storper, M. and A. Venables (2004). "Buzz: face-to-face contact and the urban economy." Journal of Economic Geography 4(4): 351.

Tao-Fang, Y. (2005). "Boundary Analysis of the Jing-Jin-Ji Global City-Region [J]." Geography and Geo-Information Science 4.

Tödtling, F., L. Lengaver and C. Höglinger (Forthcoming 2011). "Does location matter for knowledge sourcing? A study of ICT firms in two regions in Austria." European Planning Studies.

Tödtling, F. and M. Trippl (2005). "One size fits all?:: Towards a differentiated regional innovation policy approach." Research Policy 34(8): 1203-1219.

Wiig, H. and S. Herstad (2009). Prospective implications of offshored knowledge-based activities: outlook for industries in the EU and emerging economies.

Zinnov (2009). Strategic guide on Indian R\&D captives. Zinnov report.

\footnotetext{
${ }^{i}$ Some of the research questions that were driving the project were the following: Within a particular industry, what is the role of Indian and Chinese firms in terms of innovation activities? Are they truly innovators or just imitators of what the industry world leaders are doing? What can we expect in the future, in terms of innovation, from firms in China and India?

ii According to Pavitt's view (Pavitt, 1984), the geography of knowledge flows is also influenced and characterized by different industrial patterns depending on the specific driver of technological change prevailing in an industry. For the project we decided to include a science-driven industry (green biotech); scale-intensive (automotive sector), and specialized supplier (software industry).

iii For simplification, in this paper we use the term Great Beijing to refer to this extended Jinng-Jin-Ji region.

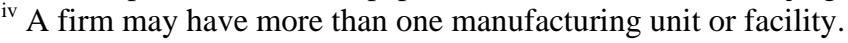

${ }^{v}$ The latest, funded in 1950 and part of the Council for Scientific and Industrial Research, is recognized as one of the most important research-oriented academic institutions in India in the field of chemical and biochemical sciences, and it is well known for its flourishing patent activity and the numerous contract researches, consultancies and training services offered not only to Indian firms but also to foreign MNCs companies Basant R., C., P. (2007). "Role of Educational and R\&D Institutions in City Clusters: An Exploratory Study of Bangalore and Pune Regions in India." World Development 35(6): 037-1055.

${ }^{\mathrm{vi}}$ In the sample related to Great Beijing region 17 firms are located outside the regional borders.

${ }^{v i i}$ In India most of the firms that answered the questionnaire were mainly pharmaceutical companies developing drugs rather than pure green-biotech companies. Therefore, the data of the two regions could not be compared.

viii All the questions in the questionnaire referred to activities conducted the year before, in this case, 2007.

Previously to this question on sources of knowledge, the firms were asked about their most important innovation in 2007 (product/process/organizational). The question of linkages naturally followed that line of enquiry, so the firms could refer to the most important innovation.

${ }^{\text {ix }}$ Interview with a principal researcher of a small spin-off company specialized in speech solutions and speech recognition. 10/November/2009.

${ }^{\mathrm{x}}$ In a sense, the behavior of the firms in Pune is very consistent to what we would expect from the knowledge based approach. Autoparts, as an industry dominated by synthetic knowledge bases relies more strongly on local sources of knowledge and technology than software firms, which rely strongly on international sources.

${ }^{x i}$ Interview with the Director General of the Mahratta Chamber of Commerce. 13/August/2009.

xii Interview with the CEO and co-founder a small software company in Pune specialized in software for the stock-exchange. 14/August/2009.

xiii Interview with the President and Executive director of a large software company in Pune. 13/August/2009.

xiv Interview with the Executive Vice-president business development of a large IT firm in Beijing. 11/November/2009

xv Interview with the Director, Global sales \& Marketing of a large Chinese/American software firm. 13/November/2009
} 


\section{CIRCLE ELECTRONIC WORKING PAPERS SERIES (EWP)}

CIRCLE (Centre for Innovation, Research and Competence in the Learning Economy) is a multidisciplinary research centre set off by several faculties at Lund University and Blekinge Institute of Technology. CIRCLE has a mandate to conduct multidisciplinary research and education on the following issues: Long-term perspectives on innovation, structural change and economic growth, Entrepreneurship and venture capital formation with a special focus on new ventures, The dynamics of R\&D systems and technological systems, including their impact on entrepreneurship and growth, Regional innovation systems in different national and international contexts and International comparative analyses of national innovation systems. Special emphasis is done on innovation policies and research policies. 10 nationalities and 14 disciplines are represented among the CIRCLE staff.

The CIRCLE Electronic Working Paper Series are intended to be an instrument for early dissemination of the research undertaken by CIRCLE researchers, associates and visiting scholars and stimulate discussion and critical comment.

The working papers present research results that in whole or in part are suitable for submission to a refereed journal or to the editor of a book or have already been submitted and/or accepted for publication.

CIRCLE EWPs are available on-line at: http://www.circle.lu.se/publications

Available papers:

2010

WP 2010/01

Innovation policies for development: towards a systemic experimentation based approach

Cristina Chaminade, Bengt-Ake Lundvall, Jan Vang-Lauridsen and KJ Joseph

WP 2010/02

From Basic Research to Innovation: Entrepreneurial Intermediaries for Research Commercialization at Swedish 'Strong Research Environments'

Fumi Kitagawa and Caroline Wigren

WP 2010/03 Different competences, different modes in the globalization of innovation?

A comparative study of the Pune and Beijing regions

Monica Plechero and Cristina Chaminade

WP 2010/04 Technological Capability Building in Informal Firms in the Agricultural

Subsistence Sector In Tanzania: Assessing the Role of Gatsby Clubs

Astrid Szogs and Kelefa Mwantima

WP 2010/05

The Swedish Paradox - Unexploited Opportunities!

Charles Edquist 
WP 2010/06

A three-stage model of the Academy-Industry linking process: the perspective of both agents

Claudia De Fuentes and Gabriela Dutrénit

WP 2010/07

Innovation in symbolic industries: the geography and organisation of knowledge sourcing

Roman Martin and Jerker Moodysson

WP 2010/08

Towards a spatial perspective on sustainability transitions

Lars Coenen, Paul Benneworth and Bernhard Truffer

WP 2010/09

The Swedish national innovation system and its relevance for the emergence of global innovation networks

Cristina Chaminade, Jon Mikel Zabala and Adele Treccani

WP 2010/10

Who leads Research Productivity Change? Guidelines for R\&D policy makers Fernando Jiménez-Sáez, Jon Mikel Zabala and José L- Zofío

WP 2010/11

Research councils facing new science and technology

Frank van der Most and Barend van der Meulen

WP 2010/12

From new to the firm to new to the world. Effect of geographical proximity and technological capabilities on the degree of novelty in emerging economies

Monica Plechero and Cristina Chaminade

WP 2010/13

Are knowledge-bases enough? A comparative study of the geography of knowledge sources in China (Great Beijing) and India (Pune)

Cristina Chaminade

2009

WP 2009/01

Building systems of innovation in less developed countries: The role of intermediate organizations.

Szogs, Astrid; Cummings, Andrew and Chaminade, Cristina

WP 2009/02

The Widening and Deepening of Innovation Policy: What Conditions Provide for Effective Governance?

Borrás, Susana

WP 2009/03

Managerial learning and development in small firms: implications based on observations of managerial work

Gabrielsson, Jonas and Tell, Joakim 
WP 2009/04

University professors and research commercialization: An empirical test of the "knowledge corridor" thesis

Gabrielsson, Jonas, Politis, Diamanto and Tell, Joakim

WP 2009/05

On the concept of global innovation networks

Chaminade, Cristina

WP 2009/06

Technological Waves and Economic Growth - Sweden in an International Perspective 1850-2005

Schön, Lennart

WP 2009/07

Public Procurement of Innovation Diffusion: Exploring the Role of Institutions and Institutional Coordination

Rolfstam, Max; Phillips, Wendy and Bakker, Elmer

WP 2009/08

Local niche experimentation in energy transitions: a theoretical and empirical exploration of proximity advantages and disadvantages

Lars Coenen, Rob Raven, Geert Verbong

WP 2009/9

Product Development Decisions: An empirical approach to Krishnan and Ulrich Jon Mikel Zabala, Tina Hannemann

WP 2009/10

Dynamics of a Technological Innovator Network and its impact on technological performance

Ju Liu, Cristina Chaminade

WP 2009/11

The Role of Local Universities in Improving Traditional SMEs Innovative Performances: The Veneto Region Case

Monica Plechero

WP 2009/12

Comparing systems approaches to innovation and technological change for sustainable and competitive economies: an explorative study into conceptual commonalities, differences and complementarities

Coenen, Lars and Díaz López, Fernando J.

WP 2009/13

Public Procurement for Innovation (PPI) - a Pilot Study

Charles Edquist

WP 2009/14

Outputs of innovation systems: a European perspective

Charles Edquist and Jon Mikel Zabala 
WP 2008/01

R\&D and financial systems: the determinants of R\&D expenditures in the Swedish pharmaceutical industry

Malmberg, Claes

WP 2008/02

The Development of a New Swedish Innovation Policy. A Historical Institutional Approach

Persson, Bo

WP 2008/03

The Effects of R\&D on Regional Invention and Innovation

Olof Ejermo and Urban Gråsjö

WP 2008/04

Clusters in Time and Space: Understanding the Growth and Transformation of Life Science in Scania

Moodysson, Jerker; Nilsson, Magnus; Svensson Henning, Martin

WP 2008/05

Building absorptive capacity in less developed countries

The case of Tanzania

Szogs, Astrid; Chaminade, Cristina and Azatyan, Ruzana

WP 2008/06

Design of Innovation Policy through Diagnostic Analysis:

Identification of Systemic Problems (or Failures)

Edquist, Charles

WP 2008/07

The Swedish Paradox arises in Fast-Growing Sectors

Ejermo, Olof; Kander, Astrid and Svensson Henning, Martin

WP 2008/08

Policy Reforms, New University-Industry Links and Implications for Regional Development in Japan

Kitagawa, Fumi

WP 2008/09

The Challenges of Globalisation: Strategic Choices for Innovation Policy

Borrás, Susana; Chaminade, Cristina and Edquist, Charles

WP 2008/10

Comparing national systems of innovation in Asia and Europe: theory and comparative framework

Edquist, Charles and Hommen, Leif

WP 2008/11

Putting Constructed Regional Advantage into Swedish Practice? The case of the VINNVÄXT initiative 'Food Innovation at Interfaces'

Coenen, Lars; Moodysson, Jerker 
WP 2008/12

Energy transitions in Europe: 1600-2000

Kander, Astrid; Malanima, Paolo and Warde, Paul

WP 2008/13

RIS and Developing Countries: Linking firm technological capabilities to regional systems of innovation

Padilla, Ramon; Vang, Jan and Chaminade, Cristina

WP 2008/14

The paradox of high R\&D input and low innovation output: Sweden

Bitarre, Pierre; Edquist, Charles; Hommen, Leif and Ricke, Annika

WP 2008/15

Two Sides of the Same Coin? Local and Global Knowledge Flows in Medicon Valley

Moodysson, Jerker; Coenen, Lars and Asheim, Bjørn

WP 2008/16

Electrification and energy productivity

Enflo, Kerstin; Kander, Astrid and Schön, Lennart

WP 2008/17

Concluding Chapter: Globalisation and Innovation Policy

Hommen, Leif and Edquist, Charles

WP 2008/18

Regional innovation systems and the global location of innovation activities: Lessons from China

Yun-Chung, Chen; Vang, Jan and Chaminade, Cristina

WP 2008/19

The Role of mediator organisations in the making of innovation systems in least developed countries. Evidence from Tanzania

Szogs, Astrid

WP 2008/20

Globalisation of Knowledge Production and Regional Innovation Policy:

Supporting Specialized Hubs in the Bangalore Software Industry

Chaminade, Cristina and Vang, Jan

WP 2008/21

Upgrading in Asian clusters: Rethinking the importance of interactive-learning Chaminade, Cristina and Vang, Jan

2007

WP 2007/01

Path-following or Leapfrogging in Catching-up: the Case of Chinese Telecommunication Equipment Industry

Liu, Xielin

WP 2007/02 
The effects of institutional change on innovation and productivity growth in the Swedish pharmaceutical industry

Malmberg, Claes

WP $2007 / 03$

Global-local linkages, Spillovers and Cultural Clusters: Theoretical and Empirical insights from an exploratory study of Toronto's Film Cluster

Vang, Jan; Chaminade, Cristina

WP 2007/04

Learning from the Bangalore Experience: The Role of Universities in an Emerging Regional Innovation System

Vang, Jan; Chaminade, Cristina.; Coenen, Lars.

WP 2007/05

Industrial dynamics and innovative pressure on energy -Sweden with European and Global outlooks

Schön, Lennart; Kander, Astrid.

WP 2007/06

In defence of electricity as a general purpose technology

Kander, Astrid; Enflo, Kerstin; Schön, Lennart

WP 2007/07

Swedish business research productivity - improvements against international trends

Ejermo, Olof; Kander, Astrid

WP $2007 / 08$

Regional innovation measured by patent data - does quality matter?

Ejermo, Olof

WP 2007/09

Innovation System Policies in Less Successful Developing countries: The case of Thailand

Intarakumnerd, Patarapong; Chaminade, Cristina

2006

WP 2006/01

The Swedish Paradox

Ejermo, Olof; Kander, Astrid

WP 2006/02

Building RIS in Developing Countries: Policy Lessons from Bangalore, India Vang, Jan; Chaminade, Cristina

WP 2006/03

Innovation Policy for Asian SMEs: Exploring cluster differences

Chaminade, Cristina; Vang, Jan.

WP 2006/04

Rationales for public intervention from a system of innovation approach: the case of VINNOVA. 
Chaminade, Cristina; Edquist, Charles

WP 2006/05

Technology and Trade: an analysis of technology specialization and export flows

Andersson, Martin; Ejermo, Olof

WP 2006/06

A Knowledge-based Categorization of Research-based Spin-off Creation

Gabrielsson, Jonas; Landström, Hans; Brunsnes, E. Thomas

WP 2006/07

Board control and corporate innovation: an empirical study of small technology-based firms

Gabrielsson, Jonas; Politis, Diamanto

WP 2006/08

On and Off the Beaten Path:

Transferring Knowledge through Formal and Informal Networks

Rick Aalbers; Otto Koppius; Wilfred Dolfsma

WP 2006/09

Trends in R\&D, innovation and productivity in Sweden 1985-2002

Ejermo, Olof; Kander, Astrid

WP 2006/10

Development Blocks and the Second Industrial Revolution, Sweden 1900-1974

Enflo, Kerstin; Kander, Astrid; Schön, Lennart

WP 2006/11

The uneven and selective nature of cluster knowledge networks: evidence from the wine industry

Giuliani, Elisa

WP 2006/12

Informal investors and value added: The contribution of investors' experientially acquired resources in the entrepreneurial process

Politis, Diamanto; Gabrielsson, Jonas

WP 2006/13

Informal investors and value added: What do we know and where do we go?

Politis, Diamanto; Gabrielsson, Jonas

WP 2006/14

Inventive and innovative activity over time and geographical space: the case of Sweden

Ejermo, Olof

2005

WP 2005/1

Constructing Regional Advantage at the Northern Edge 
Coenen, Lars; Asheim, Bjørn

WP 2005/02

From Theory to Practice: The Use of the Systems of Innovation Approach for Innovation Policy

Chaminade, Cristina; Edquist, Charles

WP 2005/03

The Role of Regional Innovation Systems in a Globalising Economy: Comparing Knowledge Bases and Institutional Frameworks in Nordic Clusters

Asheim, Bjørn; Coenen, Lars

WP 2005/04

How does Accessibility to Knowledge Sources Affect the Innovativeness of Corporations? Evidence from Sweden

Andersson, Martin; Ejermo, Olof

WP 2005/05

Contextualizing Regional Innovation Systems in a Globalizing Learning Economy: On Knowledge Bases and Institutional Frameworks

Asheim, Bjørn; Coenen, Lars

WP 2005/06

Innovation Policies for Asian SMEs: An Innovation Systems Perspective

Chaminade, Cristina; Vang, Jan

WP 2005/07

Re-norming the Science-Society Relation

Jacob, Merle

WP 2005/08

Corporate innovation and competitive environment

Huse, Morten; Neubaum, Donald O.; Gabrielsson, Jonas

WP 2005/09

Knowledge and accountability: Outside directors' contribution in the corporate value chain

Huse, Morten, Gabrielsson, Jonas; Minichilli, Alessandro

WP 2005/10

Rethinking the Spatial Organization of Creative Industries

Vang, Jan

WP 2005/11

Interregional Inventor Networks as Studied by Patent Co-inventorships

Ejermo, Olof; Karlsson, Charlie

WP 2005/12

Knowledge Bases and Spatial Patterns of Collaboration: Comparing the Pharma and Agro-Food Bioregions Scania and Saskatoon

Coenen, Lars; Moodysson, Jerker; Ryan, Camille; Asheim, Bjørn; Phillips, Peter 
WP 2005/13

Regional Innovation System Policy: a Knowledge-based Approach

Asheim, Bjørn; Coenen, Lars; Moodysson, Jerker; Vang, Jan

WP 2005/14

Face-to-Face, Buzz and Knowledge Bases: Socio-spatial implications for learning and innovation policy

Asheim, Bjørn; Coenen, Lars, Vang, Jan

WP 2005/15

The Creative Class and Regional Growth: Towards a Knowledge Based Approach

Kalsø Hansen, Høgni; Vang, Jan; Bjørn T. Asheim

WP 2005/16

Emergence and Growth of Mjärdevi Science Park in Linköping, Sweden

Hommen, Leif; Doloreux, David; Larsson, Emma

WP 2005/17

Trademark Statistics as Innovation Indicators? - A Micro Study

Malmberg, Claes 